\title{
強震ネットワークデータから構築した 広周波数帯域統計的グリーン関数とその南海地震への応用
}

\author{
包 那仁満都拉 ${ }^{1)}$ 、川瀬 博 ${ }^{2)}$
}

1) 正会員 九州大学大学院人間環境学研究院、特任助手 工博 e-mail:mandora@seis.arch.kyushu-u.ac.jp

2) 正会員 九州大学大学院人間環境学研究院、教授 工博 e-mail:kawase@seis.arch.kyushu-u.ac.jp

\begin{abstract}
要 約
本論文では、まず K-NET、KiK-net、JMA 震度計観測網の強震観測データを統計的に処理 し、地震タイプと地域特性を考慮した加速度波形の統計的経時特性と統計的スペクトル 特性を抽出した。次に作成した統計的グリーン関数を用いて想定南海地震の強震動予測 を行ったところ、過去の地震や研究結果とほぼ一致する結果が得られた。最後に非線形 応答解析モデルに想定南海地震の強震動を入力して建物群の被害予測を行ったところ、 想定南海地震震源域から近い所や海岸地域と川沿いの沖積地盤地域などの比較的地盤が 軟らかいところでは建物種別を問わず、大破以上の被害を受ける結果になった。建物構 造種別でみると低層鉄骨造建物、木造建物、中低層 RC 造建物の順に被害率が小さくなる ことが分かった。しかし、超高層建物の被害は震源域に近いところに限られており、大 阪平野など超高層建物の現存するところでは大破及び塑性変形に入る建物はなかった。
\end{abstract}

キーワード：統計的グリーン関数、想定南海地震、建物被害予測、強震観測網

\section{1. はじめに}

地震調査研究推進本部 ${ }^{1}$ によると今後発生が危惧され、万一発生すると社会的に影響が大きいとされ る活断層帯が 98 指定され、それらは、九州から北海道までの全域に分布している。その中で兵庫県南 部地震発生直前における確率と同レベルの危険性の高いグループに所属寸る活断層帯は 28 となってい る。さらに、海溝型地震は発生する確率が非常に高く、影響する地域が広く、継続時間も長くなる特 徵があり、超高層建物や巨大構造物に大きな影響を与える可能性が懸念されている。例えば、東南海・ 南海地震の今後 30 年以内の発生確率は 60\% と $50 \%$ 程度 ${ }^{1)}$ と言われており、発生すれば西日本に衝撃的 な打撃を与えると推定されている。このような海溝型地震の震源域は日本列島を囲むように分布して おり、日本全域において、地域ごとにそれぞれの状況に見合った地震防災対策を行うことが急務とさ れている。一方、全国規模で強震動ネットワークが整備され、その観測データが一般公開されている ことは、強震動研究の推進や地震防災対策の実施に貴重な役割を果たしていることは言うまでもない。

ある地域の地震被害予測を行うに当たっては、まずその地域の周辺にどのような地震が起こり（震源 特性)、生じた波動がじのように伝播してくるか(伝播経路特性)、位置する地盤構造によって地震波動 がどのように影響されるか(サイト特性)など、起こりうる強震動を予測することは非常に重要である。 強震動予測手法としてはいくつかあるが、現実には予測する地点付近で強震度記録が得られていない 場合が多く、このことを考慮して統計的方法を用いて強震動を予測することがよく報告されている ${ }^{23)}$ 。 
この方法は多数の地震記録を統計処理して、マグニチュードや震源距離などをパラメターとする簡易 な式を用い、強震動の 3 つの特性を表現する方法であり、地震動特性の評価精度は平均化により相対 的に低くなる反面、対象地点で得られた情報の質・量によらず比較的安定した地震動評価が可能であ る。次に、想定強震動に対応した被害状況を把握するために、対象地域における建物の高さ、形状、 構造種別など建物の振動特性を考慮した建物群の耐力分布を把握寸ることも欠かせない問題である。

本研究では広帯域の強震動予測およびそれを基にした地震被害予測を行う目的で、日本全国の内陸 地域と海溝付近で起きた比較的マグニチュードが大きかった 110 個の地震に対して震源特性・伝播特 性・サイト特性の分離を行い、統計的グリーン関数を作成する。作成に当たっては今までの $2 \sim 3$ 秒ま で有効な統計的グリーン関数を 10 秒まで拡張することを試みる。この統計的グリーン関数を用いて、 内陸地震・海溝型地震の震源モデルを設定寸れば、その地域における広周波数帯域の強震動を予測す ることが可能となり、設計用入力地震動の作成や地震被害想定、防災計画の策定などに用いることが できる。本稿では既往文献による想定南海地震の震源モデルのパラメターに基づき、想定南海地震に よる西日本の K-NET、KiK-net、JMA 強震観測点における強震動予測を行う。さらに、想定した南海地 震の予測強震動を過去の震度分布や研究結果と比較し、その妥当性を検討した上で、その想定南海地 震による強震動を非線形建物応答モデルに入力して、西日本における木造建物、中低層 RC 造建物、超 高層 $\mathrm{RC}$ 造建物、および鉄骨建物の被害予測を行う。今回の被害予測手法では、従来の最大值指標に結 びつけた経験的被害関数とは異なり、予測した強震動波形を非線形応答解析モデルに入力して計算寸 るので、平均被害率だけではなく、建物の構造種別や高さ、建設年代などの特性を考慮したきめ細か な予測被害率が得られ、さらに建物の破壊される階数や応答変形性状なども予測可能になる。

\section{2. 対象地震及び対象地点}

本論文では 1996 年 8 月から 2005 年 3 月にかけて、全国の地域や海岸周辺に起きたマグニチュードM $\geqq 5.5$ 、震源深さ $\leqq 60 \mathrm{~km}$ 、最大加速度 $\leqq 200 \mathrm{gal}$ （地盤が非線形化したケースを避けるため）、最大震源 距離 $\leqq 400 \mathrm{~km}$ の条件を満足し、かつ K-NET、KiK-Net、JMA 強震観測点に対して最小でも 3 点で観測でき た地震を選しだ。ただし特定の地震群によるバイアスが生じないように、同じ場所で沢山の地震が起 きた場合はその中からマグニチュードが大きな地震をいくつか選ぶようにした。また、震源距離が遠 くなるほどノイズが増える可能性を考慮して、用いるデータの震源距離の上限とマグニチュードが比 例するように観測波形を選択した。今回このような条件を満たす地震は 110 個になり、そのうち内陸 地震は 25 個、プレート内地震は 34 個、プレート間地震は 51 個であった。この地震タイプは発生した 地震の位置、震源深さ、および発震機構によって分類した。すなわち、内陸地震では震源深さが $25 \mathrm{~km}$ 以浅で震源が内陸部であること、プレート内地震は震源深さが $25 \mathrm{~km}$ 以深でプレートの沈み込み帯に位 置していること、プレート間地震はプレート内地震と同じ条件を満足し、かつ 1997 年以前はハーバー ド、それ以降は Freesia の発震機構などから低角逆断層であることと、そのすべり方向がプレートの 沈み込み方向と一致していることで判定した。対象観測点は K-NET、KiK-Net、JMA の観測点を含む 1, 684 地点であり、強震動波形データは合計 15, 935 波になった。地域特性に関しては、日本の火山や中央構 造線など考慮して全日本を 6 地域 ${ }^{4)}$ に分割した。図 1 では対象とした内陸地震、プレート間地震、プレ ート内地震の分布位置・メカニズム解・震源深さと観測点位置及び地域区分を示す。

\section{3. 統計的グリーン関数法の構築方法}

\section{1 統計的経時特性}

地震動の経時特性は、包絡形と継続時間で特徵づけられる。本研究では、経時特性の形を Boore (1983) が最初に提案 ${ }^{5)}$ した包絡線関数 $\mathrm{W}(\mathrm{t})$ でモデル化し、パラメターの同定を行う。Boore の包絡形モデルは、 継続時間 $\mathrm{T}_{\mathrm{d}}$ 、振幅が最大となるまでの時間 $\mathrm{T}_{\mathrm{r}}$ 、 $\mathrm{T}_{\mathrm{r}}$ の $\mathrm{T}_{\mathrm{d}}$ に対する比 $\varepsilon$ 、時刻 $\mathrm{T}_{\mathrm{d}}$ における振幅の最大振幅 に対する比 $\eta$ で規定される。W(t)の式を以下に示す。

$$
\begin{aligned}
& \mathrm{W}(\mathrm{t})=\mathrm{a} \cdot \mathrm{t}^{\mathrm{b}} \cdot \exp (-\mathrm{ct}) \cdot \mathrm{H}(\mathrm{t}) \\
& \mathrm{a}=\left(\frac{2.7182}{\varepsilon \cdot \mathrm{T}_{\mathrm{d}}}\right)^{\mathrm{b}}
\end{aligned}
$$




$$
\begin{aligned}
& \mathrm{b}=\frac{-\varepsilon \cdot \ln \eta}{[1+\varepsilon \cdot(\ln \varepsilon-1)]} \\
& \mathrm{c}=\frac{\mathrm{b}}{\varepsilon \cdot \mathrm{T}_{\mathrm{d}}}
\end{aligned}
$$

式(1)の H(t) は単位ステップ関数を表し、式(2)の a は関数W(t)の最大值が 1 になるように規定されて いる。まず、観測波形を $120 \mathrm{sec}$ 切り出し、前後に 2 秒のコサインテーパをつけた。その観測波形の最 大值を 1 に基準化し、その絶対值振幅の 1 秒ごとの区間最大值を取り、それに $\eta=1 / 20$ で固定した W $(\mathrm{t})$ をフィッティングさせ、各観測波形の $\mathrm{T}_{\mathrm{d}}$ と $\mathrm{T}_{\mathrm{r}}\left(=\varepsilon \times \mathrm{T}_{\mathrm{d}}\right)$ を最小自乗法により同定する。フィッティング 対象は観測波形の全域で、 $\varepsilon$ は $0.05 \sim 0.95$ の範囲を 0.02 刻みで変化させて最適值を検索した。次に、 得られた $\mathrm{T}_{\mathrm{d}}$ と $\mathrm{T}_{\mathrm{r}}$ をマグニチュード M と震源距離 X で回帰する。ここで、マグニチュード $\mathrm{M}$ と震源距離 X が相互にトレードオフになる可能性を除くため、二段階回帰分析手法を用いる。まず一段階目では、 $\mathrm{T}_{\mathrm{d}}$ を式(5)でモデル化する。

$$
\log \mathrm{T}_{\mathrm{d}_{\mathrm{ij}}}=\mathrm{a}_{\mathrm{i}}+\mathrm{b} \cdot \log \mathrm{X}_{\mathrm{ij}}+\mathrm{C}_{\mathrm{j}}
$$

$\mathrm{i}$ は地震番号、 $\mathrm{j}$ は観測点番号を表し、 $a_{\mathrm{i}}$ は震源係数、 $\mathrm{b}$ は距離係数、 $\mathrm{C}_{\mathrm{j}}$ は $\mathrm{j}$ 観測点のサイト係数であ る。震源係数 $\mathrm{a}_{\mathrm{i}}$ とサイト係数 $\mathrm{C}_{\mathrm{i}}$ を分離するための拘束条件は基準観測点 (YMGH01)のサイト係数をゼロ とした。この YMGHO1 (防府) は川瀬・松尾 ${ }^{4)}$ によって地中センサーのレベルにおいて岩盤のせん断波速 度が $3,400 \mathrm{~m} / \mathrm{s}$ 以上に達していることが報告されており、地震基盤と考えても差し支えないので、本論 文でも基準観測点とした。つぎに、二段階目では、式(6)のように M の一次式でモデル化し、一段階目 で得られた距離係数 $\mathrm{b}$ を用いて未知パラメター $\mathrm{a}$ および $\mathrm{C}_{\mathrm{j}}$ を求める。1つの観測点について NS、EW の 2 成分があるため、実際の計算では 1 つの観測点 $\mathrm{j}$ に対してNS、EW の $C_{j}$ が求まることになる。

$\mathrm{T}_{\mathrm{r}}$ についても同様に解析を行った。

$$
\log \mathrm{T}_{\mathrm{d}_{\mathrm{ij}}}=\mathrm{a} \cdot \mathrm{M}_{\mathrm{i}}+\mathrm{b} \cdot \log \mathrm{X}_{\mathrm{ij}}+\mathrm{C}_{\mathrm{j}}
$$

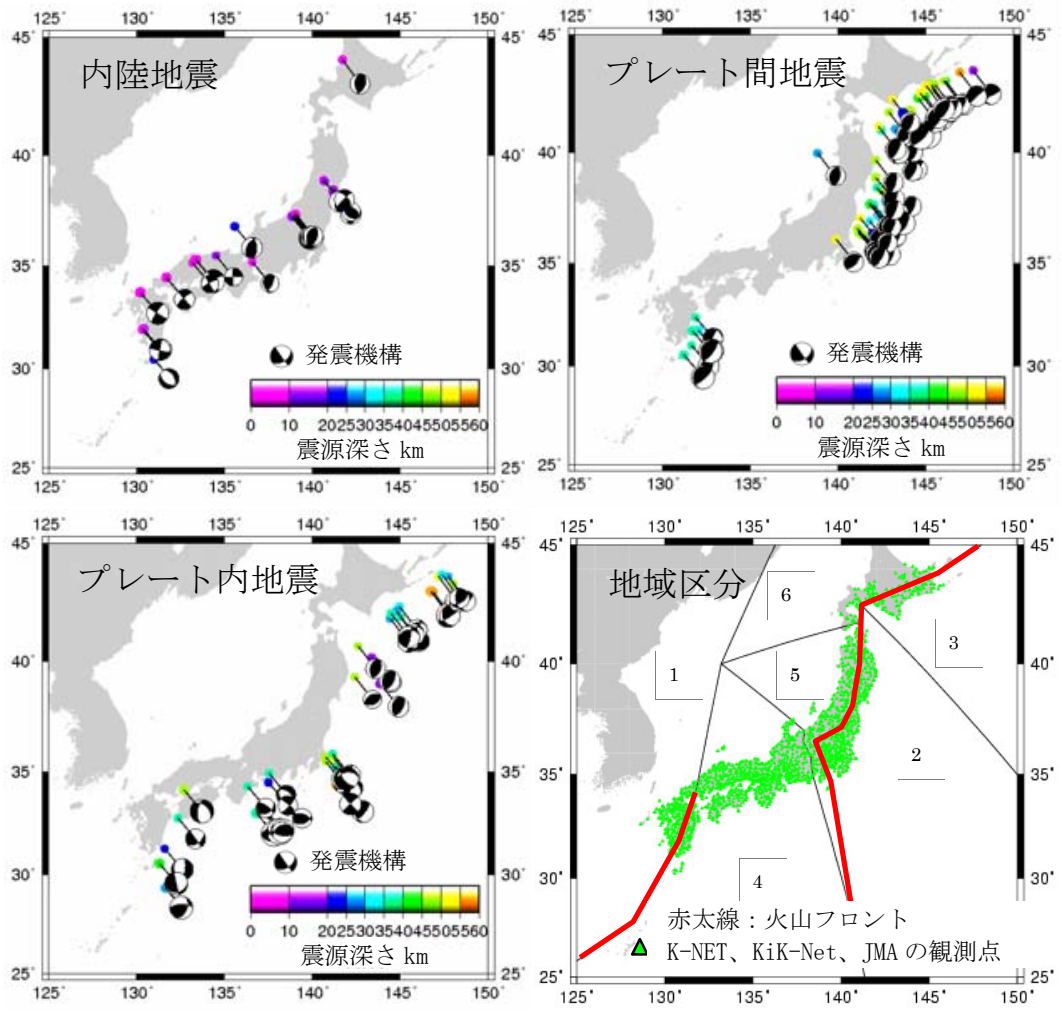

図 1 対象地震の位置分布と観測点及び地域区分図 


\section{2 統計的スペクトル特性}

次に、対象データのフーリエスペクトルから観測地震の震源特性、伝播経路特性、サイト特性を抽 出する。既に川瀬・松尾 ${ }^{4)}$ はマグニチュードが 1996 年 8 月から 2002 年 6 月までの間の $M j \geqq 4.5$ 、震源 深さ $\leqq 60 \mathrm{~km}$ 、震源距離 $\leqq 200 \mathrm{~km}$ 、最大加速度 $\leqq 200 \mathrm{gal} 、 3$ 地点以上でトリガーの条件にあう観測データ から S 波初動以降をマグニチュードに応じて（M jma $\leqq 6$ で 5 秒、6 6 M j jma $\leqq 7$ で 10 秒、 $7<\mathrm{Mjma}$ で 15 秒） 切り出して $0.3 \sim 20 \mathrm{~Hz}$ の周波数帯域に対して統計的スペクトル解析を行っている。今回は $\mathrm{Mj} \geqq 5.5$ 、震 源距離 $\leqq 400 \mathrm{~km}$ 、震源深さ $\leqq 60 \mathrm{~km}$ 、最大加速度 $\leqq 200 \mathrm{gal} 、 3$ 地点以上でトリガーの条件にあうデータを 1996 年 8 月から 2005 年 3 月まで、振動数を 0.1 20Hz まで拡張し、S 波初動以降全継続時間の観測デ ータを用いて解析を行った。フーリエスペクトル特性は次の式(7)でモデル化する。

$$
\log F_{i j}=\log S_{i}-n_{l(i)} \log X_{i j}+\sum_{k} b_{l(i) k} X_{i j k}+\log G_{j}
$$

ここで $\mathrm{k}$ は地域区分、L $(i)$ は地震のタイプ、 $\mathrm{S}_{\mathrm{i}}$ は震源による特性、 $\mathrm{G}_{\mathrm{j}}$ はサイトによる増幅特性、 $\mathrm{n}$ は幾 何減衰を表し（ただし $100 \mathrm{~km}$ までは 1.0 と仮定）、b は内部減衰を表している。フーリエスペクトルの 統計的地震動特性の抽出にはノイズレベルを考慮して $0.1 \mathrm{~Hz}$ から $20 \mathrm{~Hz}$ の範囲で行い、地震動の放射 特性の影響を小さくするため NS、EW 成分の rms 值を用いた。なおフーリエスペクトルは $0.05 \mathrm{~Hz} の$ Parzen window により平滑化している。拘束条件としては経時特性と同様に、基準観測点（YMGH01）の 地盤構造より 1 次元重複反射理論で求めた岩盤露頭から地表面一の増幅率を拘束条件として与えた。 よって他地点のサイト特性は基準観測点（YMGHO1）の仮想露頭面に対する比として求まるが、YMGH01 はその S 波速度が $3400 \mathrm{~m} / \mathrm{s}$ 以上あり地震基盤と考えても差し支えないので、得られたサイト特性は絶 対的な值と考えられる。

\section{4. 解析結果}

上記の解析方法で内陸地震と海溝型地震（プレート間地震とプレート内地震）の経時特性とスペク トル特性を求めた。図 2 では同定した内陸地震と海溝型地震の $\mathrm{T}_{\mathrm{r}} 、 \mathrm{~T}_{\mathrm{d}}$ とマグニチュード $\mathrm{M}$ 及び震源距 離 X の関係、サイト係数の方向別の比較、統計的包絡線と観測波形の対応の 1 例を示している。マグ ニチュード M や震源距離 X が大きいほど $\mathrm{T}_{\mathrm{r}}$ や $\mathrm{T}_{\mathrm{d}}$ も大きくなる傾向がある。マグニチュード M が大きい ほど断層破壊に時間がかかること、震源距離 X が大きいほど散乱の影響により見かけ速度の遅い波が 後続動を形成することによるものと考えられる。地震タイプ別として内陸地震の $\mathrm{T}_{\mathrm{r}} 、 \mathrm{~T}_{\mathrm{d}}$ は、マグニチ ユード M と震源距離 X が大きくなるほど長くなる傾向は海溝型地震ほど明確ではなく、同じマグニチ ユード $\mathrm{M}$ と震源距離 $\mathrm{X}$ に対して $\mathrm{T}_{\mathrm{r}} 、 \mathrm{~T}_{\mathrm{d}}$ は平均的に海溝型地震より小さくなることが分かった。また、 統計的に得られたパラメターによる包絡線は観測波形の経時特性をほぼ再現していることが分かる。

サイト特性に関しては、図 2 から分かるように多少バラツキが見られるものの全体としては $\mathrm{C}_{j-} \mathrm{NS}$ と $C_{j \_} E W$ はほぼ同じであった。そこで、本研究で提案する統計的経時特性のサイト係数 $C_{j}$ は $C_{j} N \mathrm{NS}$ と $\mathrm{C}_{j-} \mathrm{EW}$ の平均值とすることにした。基準観測点 (YMGHO1) の内陸地震に対する統計的経時特性 $\mathrm{T}_{\mathrm{r}} 、 \mathrm{~T}_{\mathrm{d}}$ を式 (8)、式(9)に示し、海溝型地震に対する統計的経時特性 $T_{r} 、 T_{d}$ を式(10)、式(11)に示す。

$$
\begin{aligned}
& \log \mathrm{T}_{\mathrm{r}}=0.1390 \cdot \mathrm{M}+0.4048 \cdot \log \mathrm{X}-0.9205 \\
& \log \mathrm{T}_{\mathrm{d}}=0.1164 \cdot \mathrm{M}+0.2791 \cdot \log \mathrm{X}-0.0689 \\
& \log \mathrm{T}_{\mathrm{r}}=0.0943 \cdot \mathrm{M}+0.5109 \cdot \log \mathrm{X}-1.0396 \\
& \log \mathrm{T}_{\mathrm{d}}=0.0884 \cdot \mathrm{M}+0.6868 \cdot \log \mathrm{X}-0.7946
\end{aligned}
$$

同様にして内陸地震と海溝型地震（プレート間地震とプレート内地震）の統計的スペクトル特性が 得られた。図 3 には内陸地震とプレート内地震の震源特性、散乱減衰を含む内部減衰 $b$ 、幾何減衰 $n$ 、 サイト特性をそれぞれ示す。内部減衰 b は高振動数側ほど低下寸る傾向があり、地域別に対しては内 陸地震の場合はほぼ火山フロントより背弧側の九州北西部（区分 1)、火山フロントより背弧側で東北 地方の日本海側の地域（区分 5)、九州の太平洋側・中国・四国・近畿・東海地域（区分 4)、関東・東 北の太平洋側の地域（区分 2)（区分 3 ・6 はデータなし）の順に小さくなっているが、大きな差ではな 
内陸地震
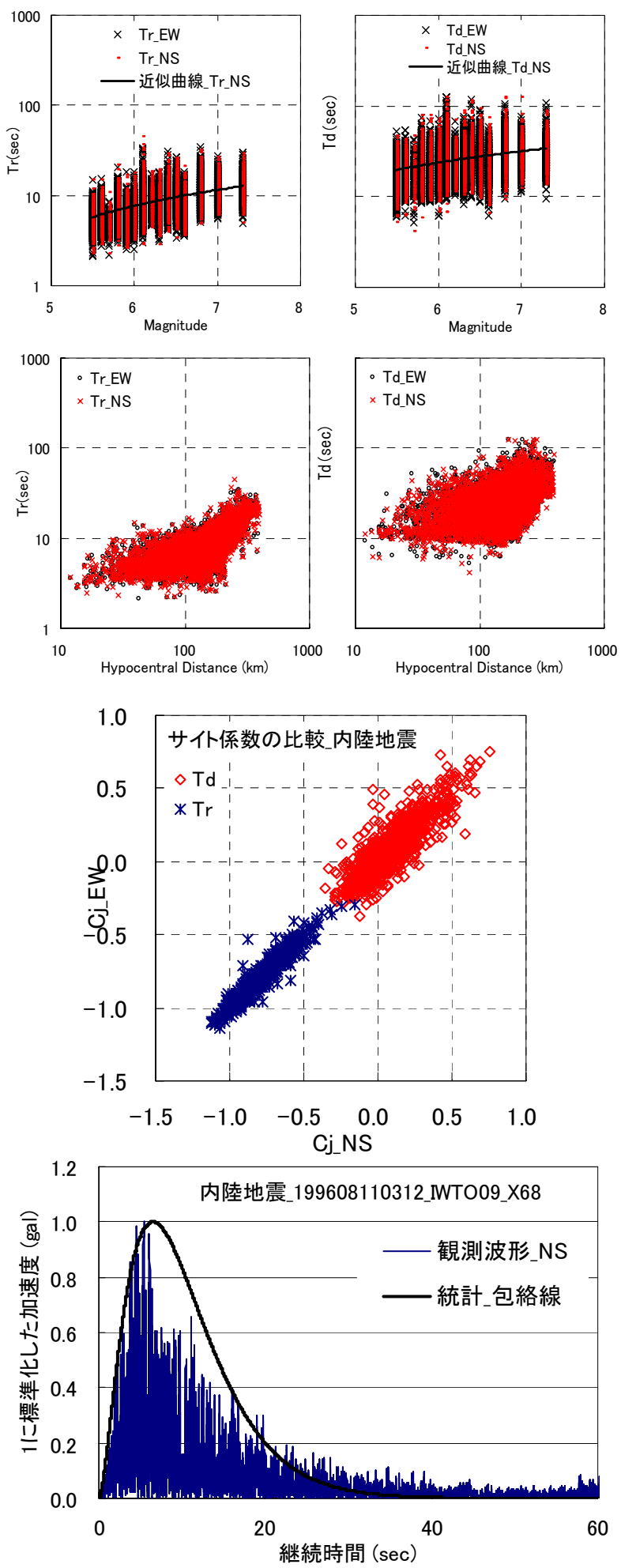

海溝型地震
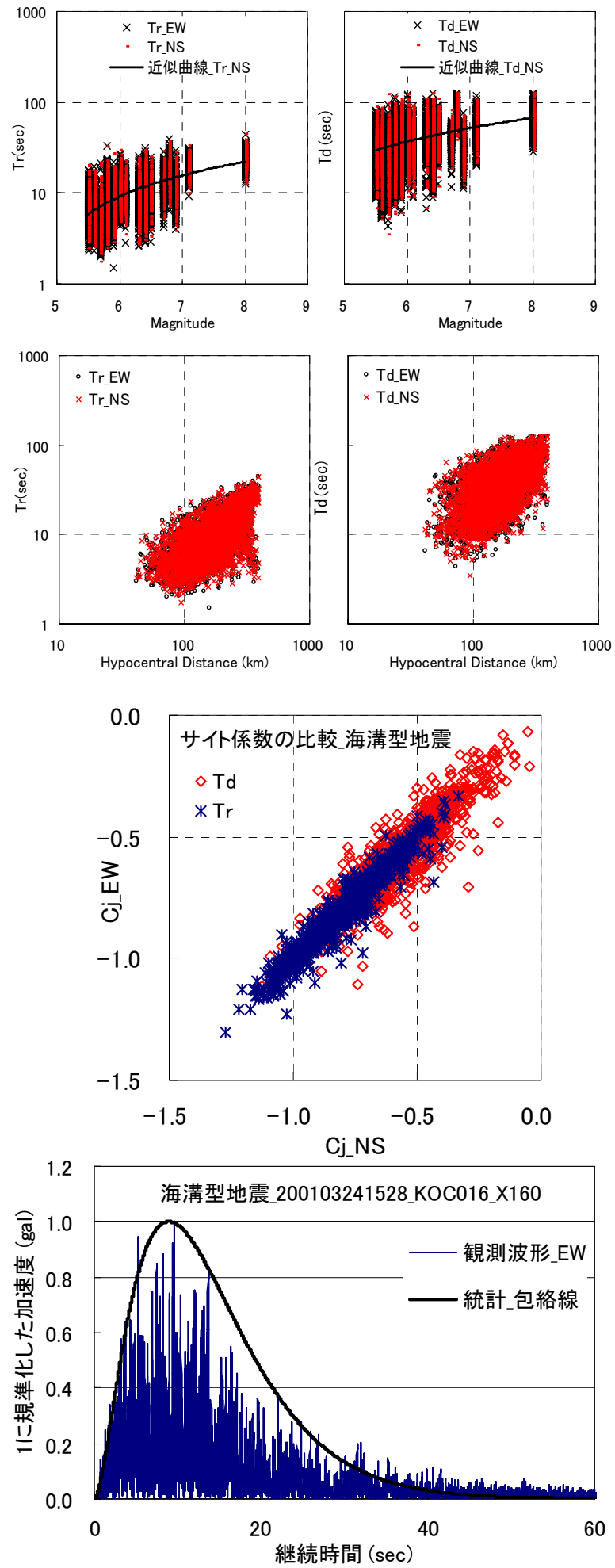

図 2 統計的経時特性 (上から $T_{r} \cdot T_{d}$ とマグニチュードの関係、 $T_{r} \cdot T_{d}$ と震源距離の関係、方向別サ イト係数の比較、統計的包絡線亡観測波形の比較）左：内陸地震、右：海溝型地震 
い。プレート内地震では火山フロントの背弧側の地域(区分 $1 \cdot 5 \cdot 6$ ) で有意に大きく（正確には負で絶

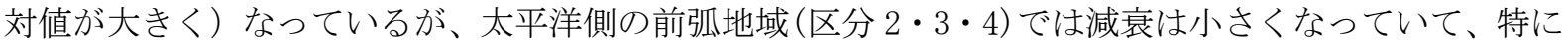
高振動数で明瞭である。また、幾何減衰 n に関しては、プレート内地震では振動数に依存せずほぼ 1 であり、実体波が卓越していることが示唆される。一方内陸地震の場合は振動数と震源距離に依存し て変動しており、低振動数（0.5Hz 以下）で遠い場合（震源距離>220 km）には 1 を超える場合も生じ ている。このときしかし内部減衰はどの地区でもゼロを超えており、内部減衰と幾何減衰によるトレ
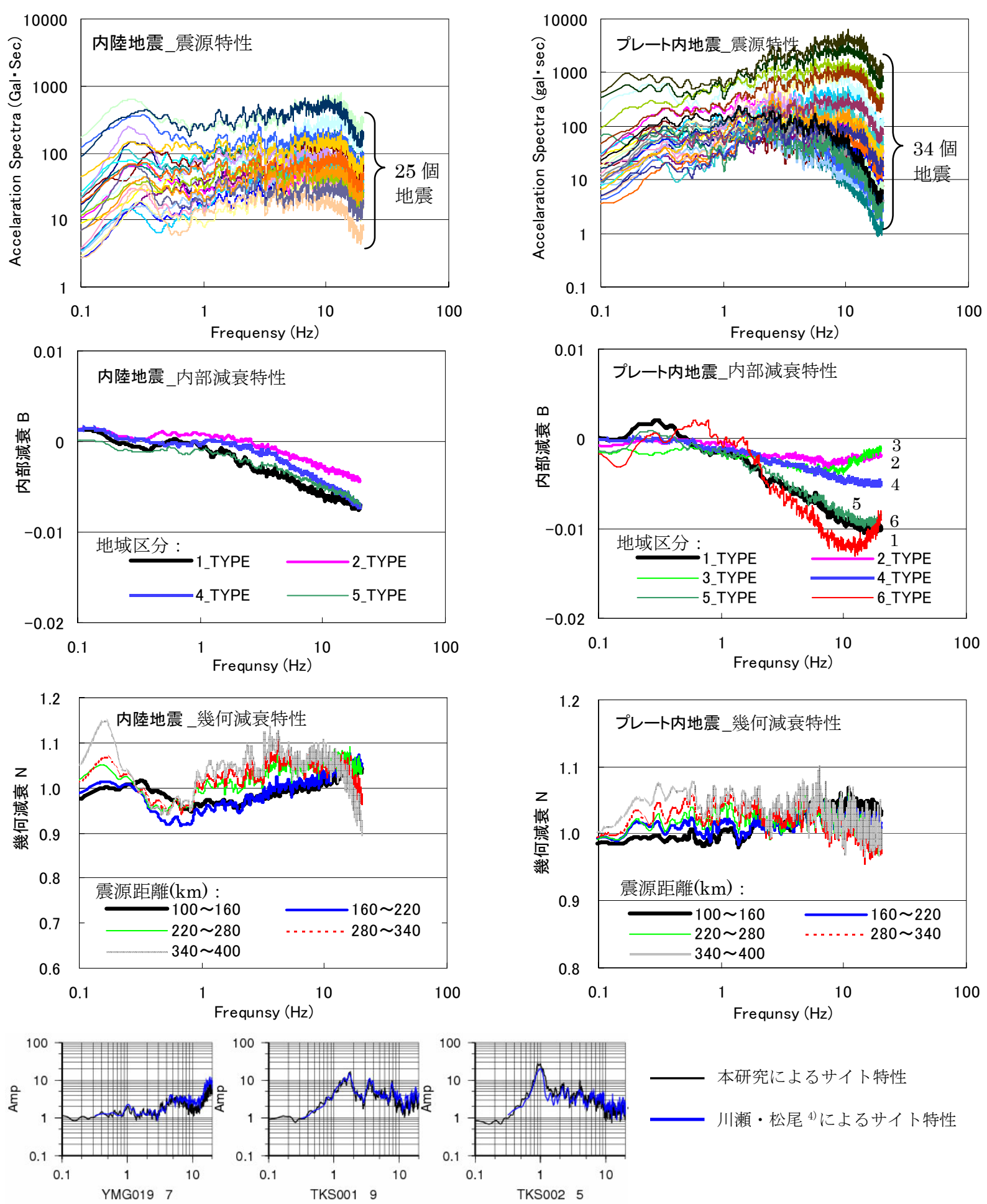

図 3 統計的スペクトル特性の例（上から震源特性、内部減衰 $b$ 、幾何減衰 $n$ 、サイト特性） 
ードオフが生じているものと思われる。S 波主要動部分だけを用いた川瀬・松尾 ${ }^{4)}$ では同じ低振動数領 域で遠い場合に幾何減衰は 1 よりも小さくなっており、長い継続時間を取ることによりスペクトルの 距離減衰性状が変わることを反映したものと解釈される。なおここでは省略したがプレート間地震の スペクトル特性もプレート内地震と殆ど同じであった。全体としては距離が遠くなるほど観測データ が少なくなるため、バラツキが大きくなると思われる。

サイト特性は全 1,684 観測点で得られたが、その例を図 3 の最下段に示す。本論文の結果を川瀬・ 松尾 ${ }^{4}$ によるサイト特性（青線）と比較すると、用いたデータの条件および解析に用いた継続時間が異 なるのに関わらずよく似ていることが分かる。震源スペクトルについても比較してみたが同じ地震に ついては両者はよく一致した。このように継続時間を全時間取ることによる影響は、直感的に考える ように、サイト特性に対する盆地生成表面波の付加的増幅として現れるのではなく、距離減衰特性に 現れるということが今回初めてわかった。

\section{5. 統計的グリーン関数を用いた想定南海地震の強震動予測}

\section{1 震源断層のモデル化及び解析地点}

想定南海地震（マグニチュード M8. 4 前後）の震源モデルは地震調查研究推進本部 ${ }^{1}$ が巨視的および 微視的震源特性の標準的設定手法（入倉レシピ）を用いて試算用に提案した震源モデル（ケース2）す なわち釜江 ${ }^{3)}$ が構築した南海地震の震源モデルを用いる。図 4 は本研究で用いた想定南海地震の震源 モデル及び解析地点を示しており、傾斜角が違う三枚の断層面から成るモデルである。星印は破壊開 始点を示す。釜江らによる想定南海地震の断層モデルと違うところは、用いた要素地震とグリーン関 数（我々は 2003 年 M6. 5 の紀伊半島沖の震源スペクトルを用いた統計的グリーン関数、釜江は 1991 年 M5. 1 の紀伊半島沖の地震の観測記録）であり、それに従い要素地震の占める断層面上のサイズも変わ る。表 1 に用いた震源モデルのパラメター及び要素地震の諸元を示す。

解析する地点は統計的グリーン関数を計算する想定南海地震のアスペリティと背景領域の中心点か ら 400km 以内の K-NET、KiK-Net、JMA 観測点で、図 4 にOで示した点であり、高知県の南西部から大 分県・宮崎県の東部を含む四国・中国・近畿を中心とした領域を対象とした。ちなみに、震源のごく 近傍のデータは元のデータセットには含まれておらず、平均的な伝播特性で外挿したことに相当する。

\section{2 合成波形とその妥当性の検討}

既に推定した海溝型地震の震源特性と伝播特性及び対象観測点ごとのサイト特性を用いて統計的グ

リーン関数を作成し、それを Irikura $(1986)^{6)}$ の波形合成法で重㸚合わせて想定南海地震の強震動波形 を作成する。その波形合成法は、 $\omega^{-2}$ 相似則 $[\operatorname{Aki}(1967)]^{7)}$ に基づき、大地震と小地震の応力降下量の 違いを考慮した波形合成方法である。

南海地震強震動評価に関してはこれまでいくつかの研究報告がある。その中で釜江ら (1994） ${ }^{8)}$ は経 験的グリーン関数法により南海地震の断層モデルの妥当性や大阪市内の観測点における強震動に関し て論じている。その後、釜江 $(2002){ }^{3)}$ は OSK008、WKY002、KOC007 の 3 箇所の K-NET 観測点に対して 統計的グリーン関数を用いた強震動予測も行っている。図 5 にその釜江らの予測結果と対応する観測 点での今回の予測強震動を比較して示した。その結果、波形の形や継続時間がよく対応していること がわかる。しかし本研究で得られた最大加速度がやや大きめとなっている一方、最大速度ほうが小さ めで、後続動部分の長周期成分の卓越が明瞭にはみられなくなっている。

図 6 に今回得られた最大加速度・最大速度と司・翠川 (1999) ${ }^{9}$ による水平最大加速度の距離減衰式 との比較を示した。想定南海地震による最大加速度は距離減衰式と概ね一致しているものといえる。 一方、司・翠川 (1999) $\left.{ }^{9}\right)$ によ速度距離減衰式は表層 $30 \mathrm{~m}$ の平均 $\mathrm{S}$ 波速度が $600 \mathrm{~m} / \mathrm{s}$ での值であり、 $\mathrm{K}-\mathrm{NET}$ ・KiK-net の全体の平均 S 波速度は $400 \mathrm{~m} / \mathrm{s}$ 程度であることを考慮した上で比較を行うと、最大速 度については全体的に小さいことが分かる。そこで要素地震の観測最大速度を速度距離減衰式と比較 してみたところ、やはりこの図と同程度に観測值が小さく得られ、震源スペクトルを利用したこの地 震自体の最大速度が有意に小さい地震であったことが分かった。もちろん、統計的グリーン関数を生 成する際に、経時特性を加速度波形で決めていることから，その包絡形は主として短周期成分で支配 され、やや長周期成分の寄与が大きい最大速度については直接的には何も規定されていないことも影 響しているものと考えられるので、今後、データを追加して分離特性の安定性を増大させることとと もに、最大速度を支配しているやや短周期からやや長周期帯域の位相特性のモデル化に関して改良を 


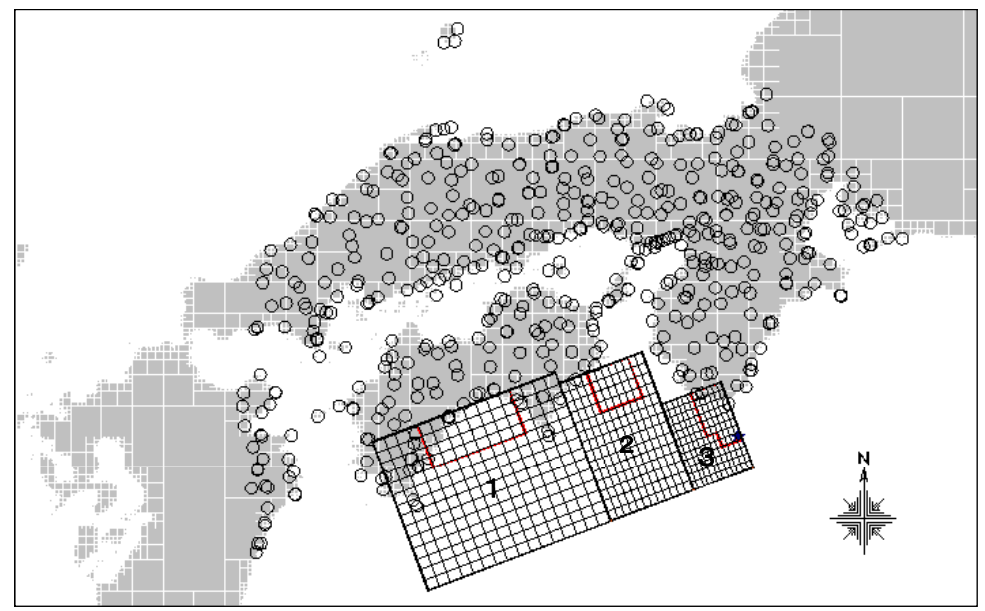

$\square$ アスペリティ $\star$ 破壊開始点 $\bigcirc$ 観測点

図 4 想定南海地震の震源モデル及び対象地点

表 1 断層モデルのパラメター及び要素地震

\begin{tabular}{|c|c|c|c|c|c|c|}
\hline & \multicolumn{2}{|c|}{ 断層面 1} & \multicolumn{2}{|c|}{ 断層面 2} & \multicolumn{2}{|c|}{ 断層面 3} \\
\hline サイズ(km) & \multicolumn{2}{|c|}{$162 * 133$} & \multicolumn{2}{|c|}{$73 * 124$} & \multicolumn{2}{|c|}{$53 * 80$} \\
\hline 面積 $\left(\mathrm{Km}^{2}\right)$ & \multicolumn{2}{|c|}{21599} & \multicolumn{2}{|c|}{9069} & \multicolumn{2}{|c|}{4213} \\
\hline 走向 $(\theta)$ & \multicolumn{2}{|c|}{250.7} & \multicolumn{2}{|c|}{250.7} & \multicolumn{2}{|c|}{250.7} \\
\hline 傾斜角 $(\delta)$ & \multicolumn{2}{|c|}{8.4} & \multicolumn{2}{|c|}{$\frac{9.5}{1027}$} & \multicolumn{2}{|c|}{17.4} \\
\hline すべり角 & \multicolumn{2}{|c|}{122.7} & \multicolumn{2}{|c|}{122.7} & \multicolumn{2}{|c|}{122.7} \\
\hline & アスペリティ 1 & 背景領域 1 & アスペリティ 2 & 背景領域 2 & アスペリティ 3 & 背景領域 3 \\
\hline 地震モーメント $(\mathrm{N} \cdot \mathrm{m})$ & $1.69 \mathrm{E}+21$ & $3.56 \mathrm{E}+21$ & $5.01 \mathrm{E}+20$ & $1.49 \mathrm{E}+21$ & $4.98 \mathrm{E}+20$ & $5.6246 \mathrm{E}+20$ \\
\hline 面積 $\left(\mathrm{Km}^{2}\right)$ & 3086 & 18514 & 1296 & 7774 & 1287 & 2926 \\
\hline 実効応力 (Mpa) & 20.1 & 2.7 & 20.1 & 2.7 & 20.1 & 2.7 \\
\hline 立ち上がり時間(sec) & 3.4 & 0.5 & 2.9 & 0.5 & 2.7 & 0.5 \\
\hline 全面積(Km2) & \multicolumn{6}{|c|}{34882} \\
\hline 地震モーメント(N·m) & \multicolumn{6}{|c|}{$8.3 \mathrm{E}+21$} \\
\hline 平均応力降下量(Mpa) & \multicolumn{6}{|c|}{3.0} \\
\hline せん断剛性率 $\left(\mathrm{N} / \mathrm{m}^{2}\right)$ & \multicolumn{6}{|c|}{$4.09 \mathrm{E}+10$} \\
\hline 破壊伝播速度(km/s) & \multicolumn{6}{|c|}{2.7} \\
\hline 震源域のS波速度 $(\mathrm{km} / \mathrm{s})$ & \multicolumn{6}{|c|}{3.0} \\
\hline 破壊伝播形式 & \multicolumn{6}{|c|}{ 放射状 } \\
\hline
\end{tabular}

検討する必要があろう。ただし、M8.4クラスの観測最大值は司・翠川(1999)の経験的距離減衰式 を作成する際のデータベースにはほとんど含まれておらず、この結果自体が外挿であることに注 意が必要である。

今回の想定南海地震における計測震度から求めた震度階級と推本の公開資料 ${ }^{10)}$ による想定東南海地 震における県庁所在地等の震度試算結果を図 7 に比較して示した。今回の震度階級の震度 6 弱及び震 度 6 強相当以上が推本の最高ランク震度 6 弱相当以上と対応するもので、その他はほぼ同じ階級で表 示している。本論文で用いた想定南海地震の強震動は、断層近傍ではレベルが飽和する現象や地盤非 線形特性などを考慮していないこと、推本による図 7 に記述しているように震源特性には不確定性が あり、また設定した地盤構造はたとえ同一市町村でも場所によるばらつきは避けられないので、震度 階級で 1 は上や下になることがあることを前提として両者を比較すれば、全体的な震度階級分布はよ く一致していると言える。

以上のように今回の想定南海地震の強震動予測は最大速度レベルが過小評価になっているものの、 過去の地震動分布、既往の研究成果とほぼ一致していることから観測データを用いた地震タイプ、地 域別に考慮して作成した統計的グリーン関数は妥当であると考えられる。そこで最後にその予測した 想定南海地震の強震動を用いて対象地域における構造物の地震被害予測を行う。しかし、本研究の計 
算事例ではその最大速度レベルが外捙した経験式に比べて過小評価傾向にあることから、以下で実施 する建物被害予測も過小評価されている可能性があることに注意されたい。

\section{6. 想定南海地震による西日本における建物の被害予測}

\section{1 入力地震動と建物群の被害予測手法}

入力地震動としては構築した想定南海地震における加速度波形を用いる。これまでの解析経験から 最大加速度が $200 \mathrm{Gal}$ 以下ではほとんどの建物には被害（大破以上）が生じないことから、想定南海 地震の震源域から $400 \mathrm{~km}$ 以内の K-NET、KiK-net、JMA 観測点における最大加速度が $200 \mathrm{Gal}$ (以下の 被害分布図の中では入力として用いた観測点に網かけをして区別している）以上になる波形を選んで 入力地震動にする。一方、建物モデルとしては、長戸・川瀬建物群非線形応答解析モデル ${ }^{11)}{ }^{12}$ と超高 層 $\mathrm{RC}$ 造建物のせん断質点系モデル ${ }^{14)}$ および微動非線形応答解析モデル ${ }^{13)}$ など三種類の非線形応答解 析モデルを用いる。

想定南海地震による建物の被害予測を行うに当たって、最大加速度が $200 \mathrm{Gal}$ 以上の観測点にそれ ぞれ三種類の非線形応答解析モデルが存在すると仮定し、その非線形建物モデルに想定強震動を入力 して建物の最大応答層間変形角、建物の大破被害率、建物の変形性状を予測する。その予測結果を非 線形応答モデルごとに以下に述べる。

\section{2 長戸・川瀬建物群非線形応答解析モデル ${ }^{11)}{ }^{12)}$ による建物群の被害予測}

長戸・川瀬は兵庫県南部地震による観測被害率と松島・川瀬 ${ }^{15)}$ による再現強震動に基づいて非線形 地震応答解析を実施し、実被害率を再現できるような年代区別なしの木造 2 階建モデル、新・旧耐震 を区別した RC 造の 3 階建モデル（2 階と 4 階を含む）、6 階建モデル（5階と 7 階を含む）、9 階建モデ ル (8 階と 10 階を含む)、12 階建モデル（11 階と 13 階を含む）、鉄骨造の 3 階建モデル、4 階建モデ ル、5 階建モデルなど合計 15 個の非線形忘答解析モデル ${ }^{11)}{ }^{12}$ をを構築している。木造建物モデルのクラ イテリオンに関しては、新耐震と旧耐震の建築年代によらず同じで、最大層間変形角で $1 / 10 \mathrm{rad}$ 以上 になったモデルが大破以上の被害を受けたものとし、RC 造建物と鉄骨建物は新耐震と旧耐震の建築年 代によらず同じく、1 層でも最大層間変形角で $1 / 30 \mathrm{rad}$ 以上になったモデルは大破以上の被害を受け たものと仮定している。また、それぞれのモデルに対しては、建物の耐力のバランスを考えて耐力が 小さいモデル、標準モデル（最頻值モデル）、耐力が大きいモデルなど 12 個のモデルが含まれており、 各モデルの存在比率を対数正規分布で与え、それらのモデルの被害の有無から被害率を算定している。 まず長戸・川瀬(2001） ${ }^{11)}{ }^{12)}$ の木造モデル・RC 造モデル・S 造モデルに想定南海地震における $200 \mathrm{Gal}$ 以上の加速度波形を入力して建物の被害を算定した。その結果表 2 で示している観測点における建物 で大破以上の被害が出ることが分かった。図 8〜図 10 の左側では建物被害率を構造種類ごとから一つ 例として示している (OLD：旧耐震建物を指す)。1946 年南海地震 ${ }^{16)}$ では高知県の高知市と四万十市 (当 時は中村町で倒壊率は 8 割)、安芸市をはじめ、和歌山県の新宮市、田辺市も比較的に被害が大きかっ た地域であった。能島暢呂 ${ }^{177}$ による木造家屋の全壊率（震度）は佐賀町、高知市、安芸市ではそれぞ れ約 $4.14 \% 、 2.3 \% 、 1.2 \%$ となっており、和歌山県の新宮市、田辺市の全壊率は $4.21 \% 、 5.08 \%$ とな つていて、被害率が今回の被害率より小さいことが分かる。今回の建物の被害予測は兵庫県南部地震 で大破した建物を対象として、実被害率と合うように構築したモデル群を用いており、そのモデル群 と同じような耐力を持つ建物が対象観測点の近傍に建てられている場合の推定被害率であることに注 意すべきである。上記の前回の南海地震における市町村別の被害率は広域の市町村全体での被害率で あり、その中で地震動の強さは場所によって異なっていたと推定される。そのため今回のピンポイン トでの予測被害率とは同レベルで比較することは難しい。一方、長戸・川瀬モデルも新潟県中越地震 や福岡県西方沖地震での実際の被害率と比較して過大評価となる傾向があることがわかっており、今 後ともその精度向上を追及する必要がある。

また、全体の被害率分布状況を中央防災会議 ${ }^{18}$ によよる図 11 に示した建物被害棟数の分布（ただし液 状化による被害棟数が含まれている）と比較すると、建物被害棟数が多いところほど、今回の算定被 害率が高くなっており、建物被害分布としては対応していると言える。なお、我々の予測結果で、大 阪湾と播磨灘、燧灘の沿岸地域における被害率が小さくなっているのは、図 11（南海地震が単独に起 きた場合の液状化による被害棟数の図は見つからなかった）で示しているように、中央防災会議の予 


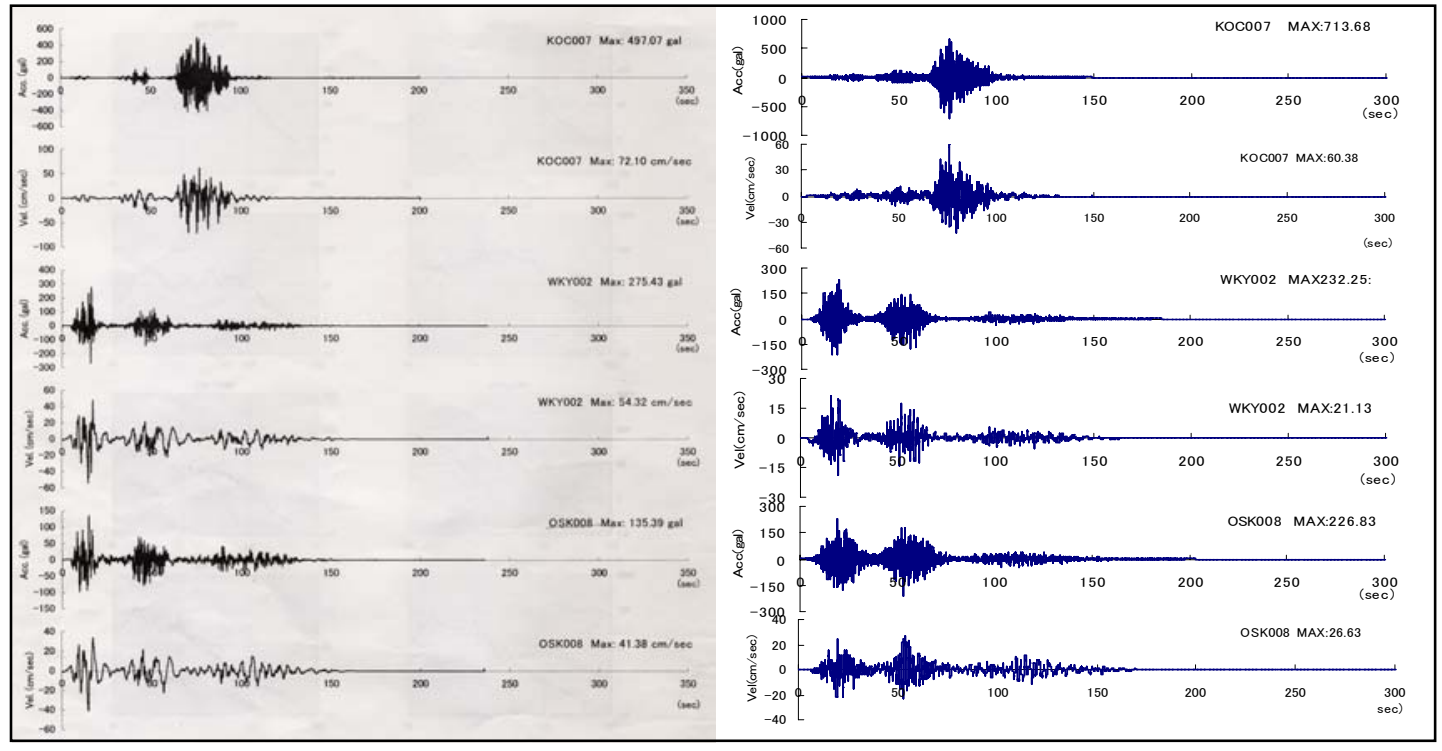

図 5 釜江の統計的グリーン関数法による合成波形（左）と今回の合成波形（右）との比較
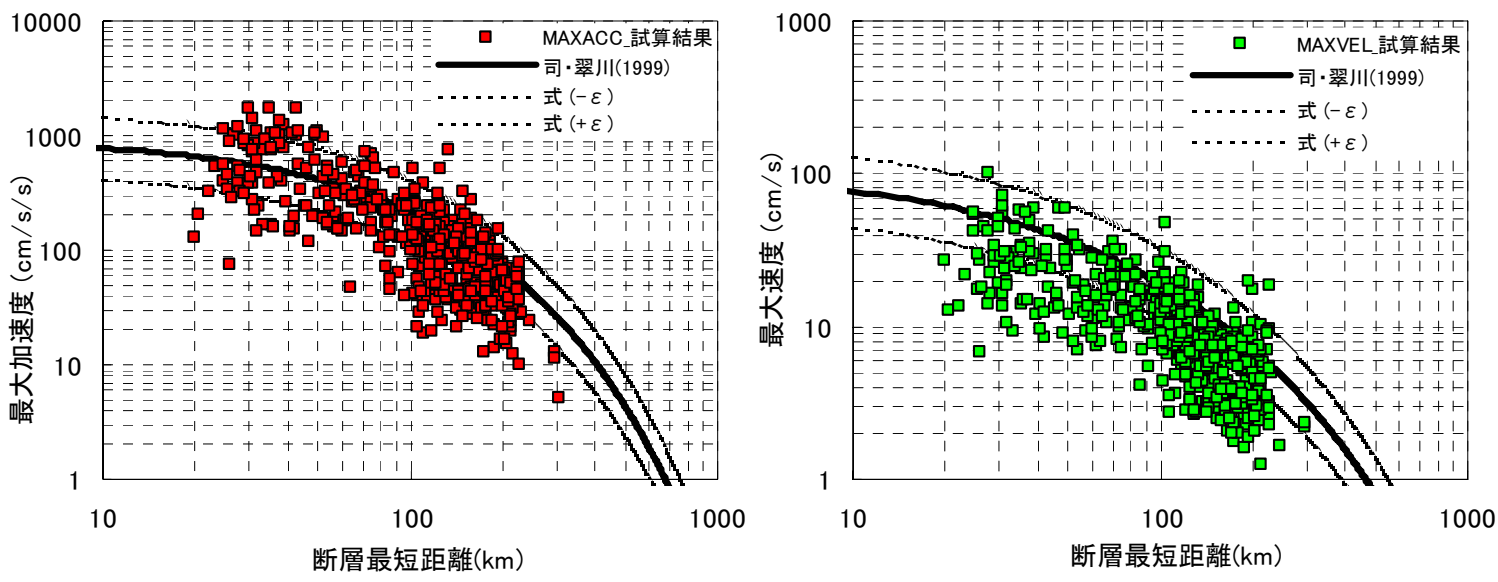

図 6 最大加速度・最大速度と司・翠川(1999)による距離減衰式との比較
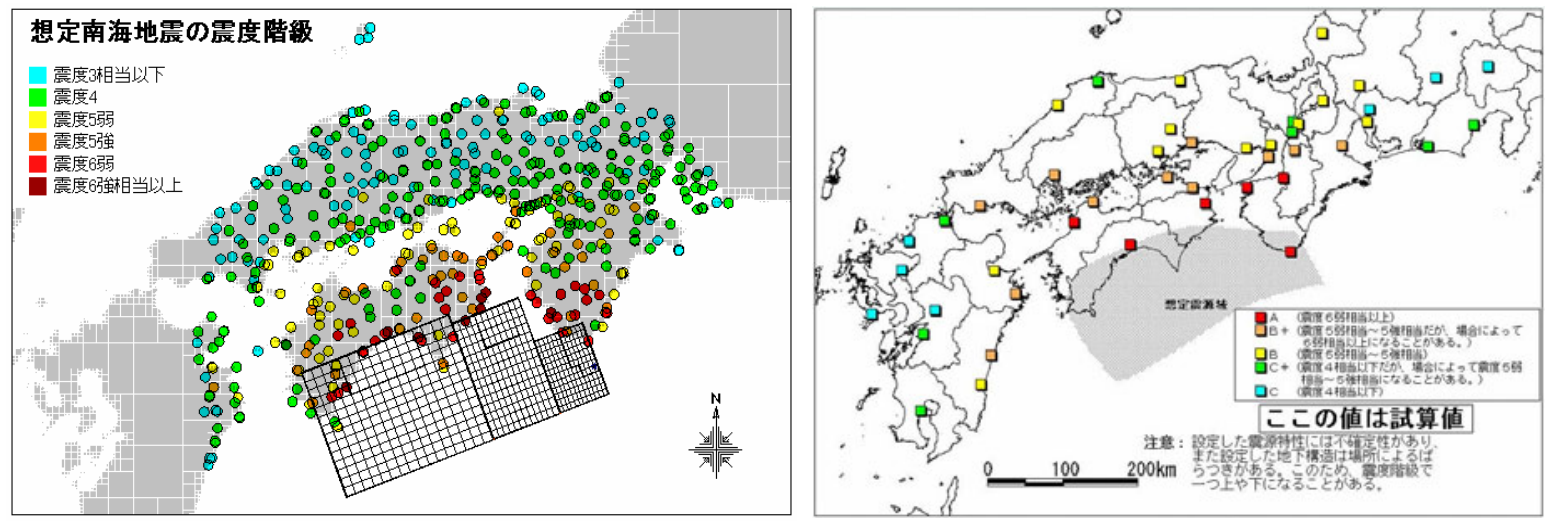

図 7 今回の想定南海地震による震度階級と推本の公開資料による想定南海地震における県庁所 在地等の震度試算結果（右）との比較 
測では液状化による建物被害が比較的多く、摇れによる大破以上の被害が少なくとも被害総数が多く なるためと考えられる。

図 8〜図 10 の右側では一つの例としてKOC007 観測点 (図 8 に示している赤丸の真ん中の点) における 木造建物、3 階、6 階、9 階、12 階 RC 造建物、3 階、4 階、5 階 $\mathrm{S}$ 造建物の中で一般的な耐力を持つ標 準モデルの最大応答層間変形角を示している。一般的な耐力を持つ木造建物と中低層 $\mathrm{RC}$ 造建物の層間 変形角がクライテリオン（1/10 rad、1/30 rad）より小さく大破以上の被害を受けないことが分かる。 そのことから、図 8〜図 10 の左側で被害が出ている建物は一般的な建物より耐力が小さい建物である ことが分かる。一方、 $\mathrm{S}$ 造建物モデルに対しては、一般的な耐力を持っていても、4 階と 3 階建物で 1 階・2 階の部分が大きく変形して大破以上の破壊を受けることが読み取れる。

そのほかの建物も同じような結果であり、全体的に建物の被害分布状況が殆ど海岸地域と川に沿っ ており、比較的地盤が軟らかい地域に分布しているのが特徵である。建物構造種類別でみると低層鉄 骨造建物、木造建物、中低層 RC 造建物の順に被害率が小さくなることが分かった。また、当然のこと ながら新耐震建物の被害率は旧耐震建物の被害率より小さかった。

表 2 想定南海地震で木造と低・中層 RC・鉄骨造建物が大破以上の被害を受ける観測点

\begin{tabular}{|l|l|}
\hline \multicolumn{1}{|c|}{ 所在県 } & \multicolumn{1}{|c|}{ K-NET、KiK-Net、JMAの観測点名 } \\
\hline 高知県 & KOC002、KOC003、KOC007、KOC013、KOC014、F35、598、599 \\
\hline 德島県 & TKS001、TKS002、TKS003、TKS004、TKS006、TKS007、TKS010、F37、592、593、974、975 \\
\hline 和歌山県 & WKY002、WKY005、WKY006、WKY008、WKY009、WKY012、WKY014、WKYH07、WKYH10、58B、96B \\
\hline 香川県 & KGW005、KGW007、978、594 \\
\hline 愛媛県 & EHM012、EHM016 \\
\hline 大阪府 & OSK008 \\
\hline 奈良県 & NARH01 \\
\hline 大分県 & OIT013 \\
\hline
\end{tabular}
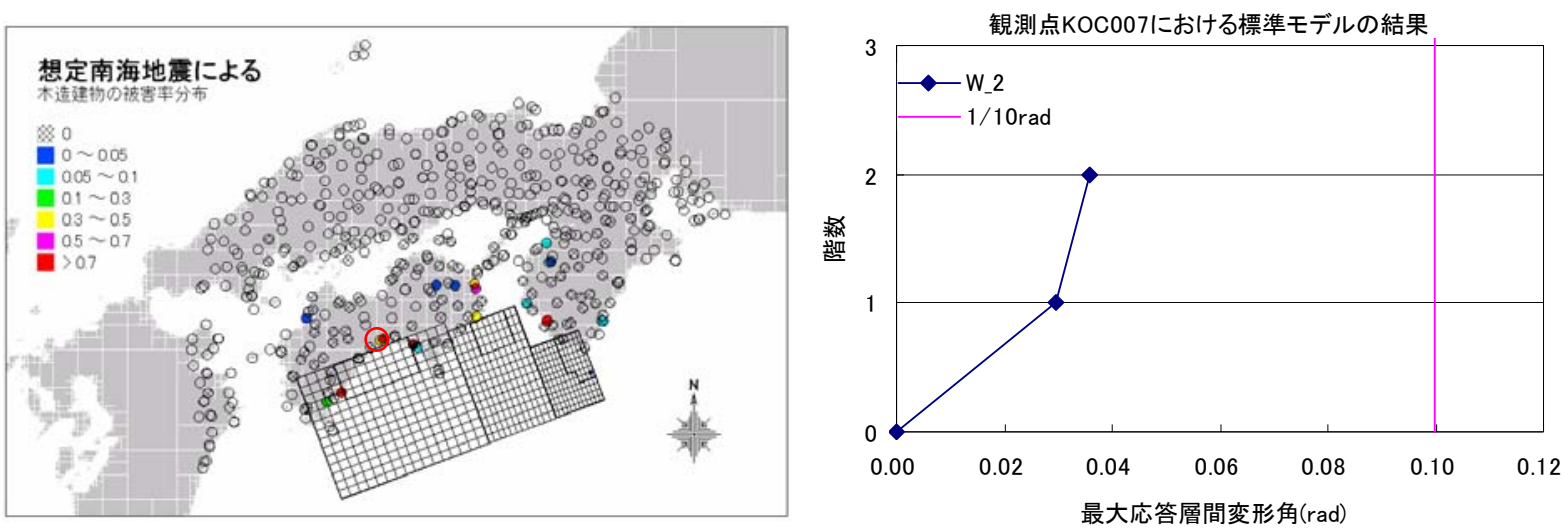

図 8 木造建物の被害率分布と振動状況の例
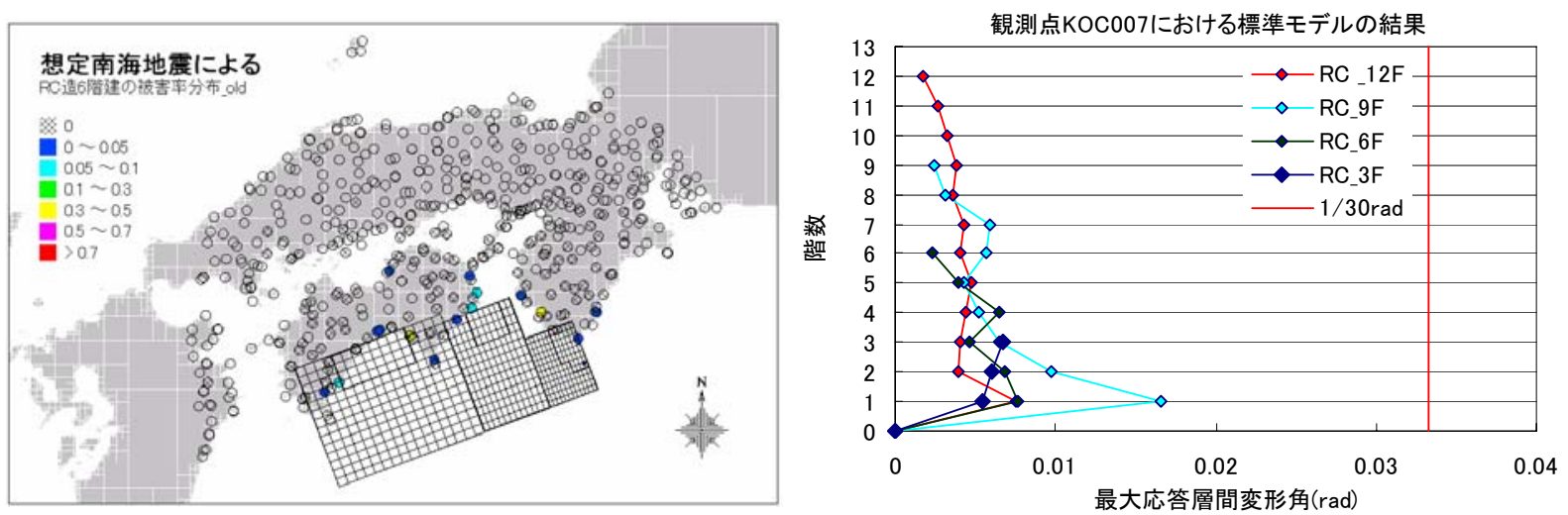

図 9 想定南海地震による旧耐震 RC 造 6 階建の被害分布と振動状況の例 

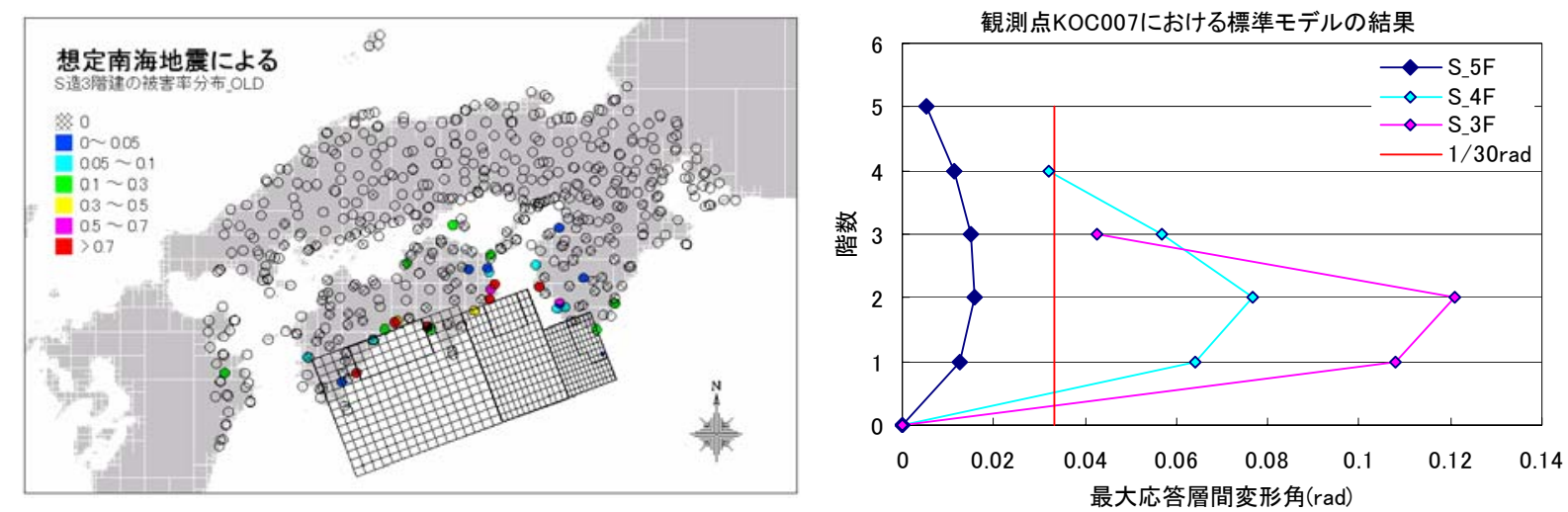

図 10 想定南海地震による旧耐震鉄骨造 3 階建の被害分布と振動状況の例

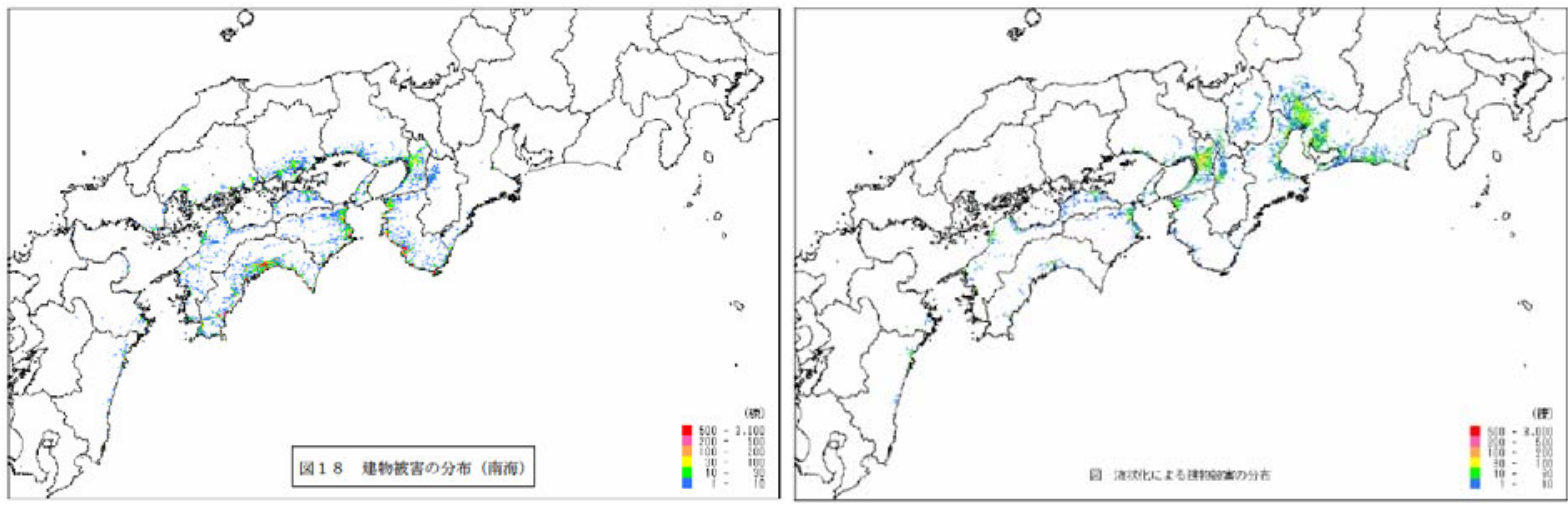

図 11 中央防災会議 ${ }^{18)}$ による建物被害の分布（南海）と液状化による被害分布（東南海・南海）

\section{3 超高層 RC 造建物のせん断質点系モデルによる建物群の被害予測}

金・川瀬 ${ }^{14)}$ は日本建築センター評定に関する公開情報に基づいて、せん断質点系による 19 階、21 階、23 階、25 階、30 階、33 階、35 階、38 階建 RC 造非線形モデルを構築している。構築手法として は、Degrading tri-linear 型の第 1 次降伏点に対応寸る建物剛性を設計時の一次固有振動数から同定 し、第二次剛性は第一剛性と剛比 $\left.{ }^{11)}{ }^{12}\right)$ から求め、第 3 剛性は第 1 剛性の $1 / 1000$ と仮定した。モデルパ ラメターの設定にあたっては、ビルディングレターの応答変位結果から逆算を行った。そこで、逆算 から得られた建物に対応するモデルを標準建物モデルとする。破壊クライテリオンは $1 / 30 \mathrm{rad}$ とし、 降伏点限界は $1 / 125$ に設定した。

想定南海地震における超高層 RC 造建物の最大層間変形角が $1 / 30 \mathrm{rad}$ 以上になった建物が大破以上の 被害を受けると仮定し、最大層間変形角が 1/30rad〜 1/125rad になると降伏点を超え塑性変形が生じ たものとし、その最大層間変形角が 1/125rad 以下なら無被害として解析を行った。その結果表 3 で示 している観測点において超高層建物に大破及び塑性変形が生じることが分かった。

一つの例として 38 階 RC 造建物の最大層間変形角分布を図 12 の左側に示す。被害が生じる地域は、 震源断層から近い海岸地域と、その他は徳島県の吉野川に沿うように分布している。そのほかの階数 の超高層建物も地域的な最大層間変形角分布状況はほぼ同じような形となった。このように超高層建 物の推定被害は震源断層の近いところに限られており、大阪平野など超高層建物の現存寸るところで は大破及び塑性変形に入る建物はなかった。ただし、この超高層建物の被害予測モデルは未だ実被害 によるキャリブレーションができていないものなので、この超高層 $\mathrm{RC}$ 造建物の予測結果がどの程度妥 当かについては推測の域を出ない。

図 12 の右側に一つの例として KOC007 観測点における超高層 RC 造建物の最大応答層間変形角を示し ている。KOC007 観測点においては 8 棟のモデルのうち殆どの超高層建物の最大層間変形角が 1/125 以 上になり、さらにちょうど半分の超高層建物が大破以上の被害を受ける結果になった。 

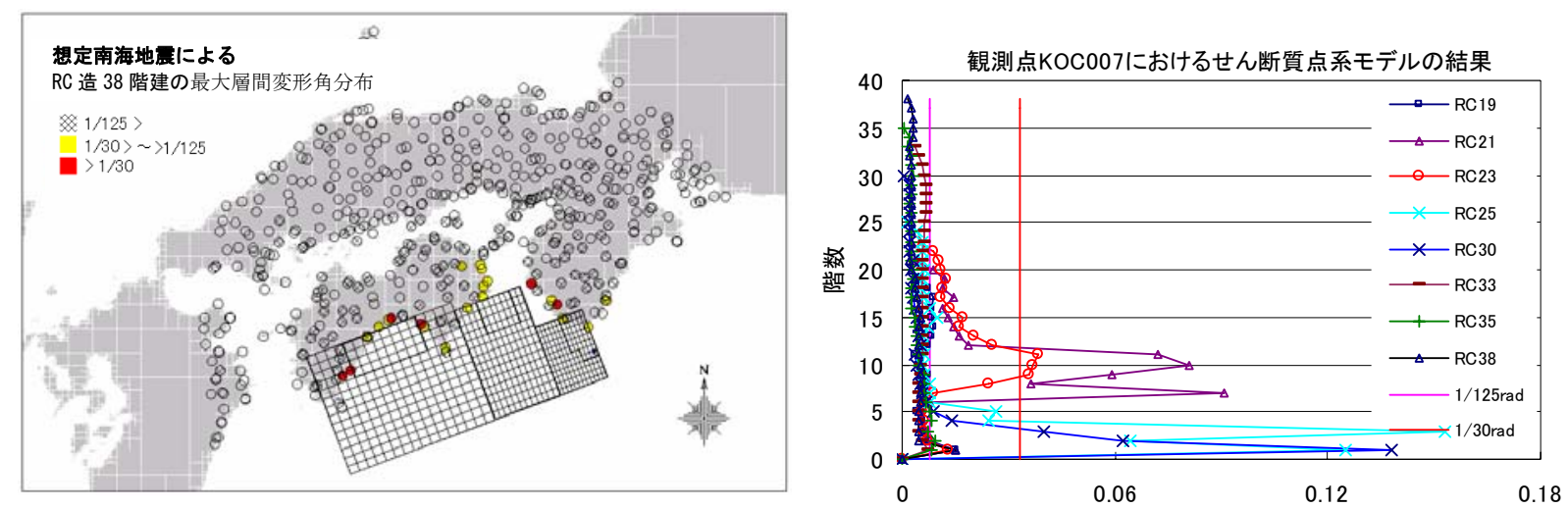

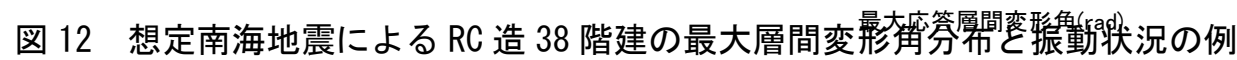

表 3 想定南海地震で超高層建物が大破及び塑性変形が生じる観測点

\begin{tabular}{|c|l|}
\hline 所在県 & \multicolumn{1}{|c|}{ K-NET、KiK-Net、JMAの観測点名 } \\
\hline 高知県 & KOC013、KOC007、KOC003、F35、598、KOC002、97B、KOC014、599、KOC006 \\
\hline 徳島県 & TKS006、593、TKS002、F37、TKS004、TKS003、974、TKSH02、975 \\
\hline 和歌山県 & WKY008、WKYH07、WKY006、WKY012、96B、WKY010、58B \\
\hline 香川県 & 978 \\
\hline 奈良県 & NARH01 \\
\hline
\end{tabular}

\section{4 微動非線形応答解析モデルによる建物群の被害予測}

微動非線形応答解析モデル ${ }^{19)}$ とは福岡市に位置する 2 階から 6 階建の 21 棟 RC 造建物と 2 階建の 3 棟木造建物によるモデルを指している。それぞれの建物の設計図書や微動計測結果から得られた実（観 測）剛性と長戸・川瀬 ${ }^{11}{ }^{122}$ が用いた仮定に基づいて構築したモデルであり、2005 年 3 月 20 日に起きた 福岡県西方沖の地震による建物の実被害と応答シミュレーションから一部のモデルの妥当性を検証し ている。

本論では実際に存在する福岡市の 21 棟の RC 造建物と 3 棟の木造建物が想定南海地震における対象 とする観測点に建てられているか、それとも同じ耐力を持つ建物があると仮定し、それぞれのモデル に想定南海地震の強震動加速度波形を入力して応答解析を行った。その時 $\mathrm{RC}$ 造建物と木造建物の最大 層間変形角が 1/30 rad と 1/10 rad を超えると大破以上の被害を受けるものとする。木造建物に関し ては棟数が少ないため、それぞれの観測点において大破以上の被害を受けるかないかを検討する。 RC 造建物に対してはある観測点において 21 棟の建物の中で、何棟が大破以上の被害を受けるかを計算し、 それを全棟数でわり、2 階から 6 階建 RC 造建物の平均被害率を出すことにした。

図 13 の左側では想定南海地震による実測 RC 造建物の全体被害率を示しており、高知県の 598 観測 点では最大で 42\%になり、徳島県の TKS004、593 では 10〜30\%になり、和歌山県の WKY006、WKY008、 WKYH07、WKY012、58B など観測点において大破以上の被害が 5〜30\%になった。図 14 の左側では同じ く想定南海地震による実測木造建物の被害レベルを示しており、四万十市、高知市、安芸市、徳島市、 田辺市などでは実木造建物 3 棟とも大破以上の被害を受けることが分かった。これらは前節の 3 階、6 階建の長戸・川瀬 ${ }^{11}{ }^{12}$ ) による RC 造、木造建物の被害分布とほぼ一致しており、ここでの被害率のほう が同じか多少小さい評価になった。その高知県の四万十市、高知市、安芸市や和歌山県の新宮市、田 辺市、串本町などところは 1946 年南海地震で比較的に被害が大きかった地域でもあり ${ }^{16)}$ 、今回の被害 分布は過去の地震のそれとほぼ対応していることが分かる。

図 13、図 14 の右側では一つの例として KOC007 観測点に福岡市の 21 棟の RC 造建物の中から階数別 に 5 棟、木造建物 3 棟の最大応答層間変形角を示している。福岡市に位置寸る RC 造建物が KOCO07 観

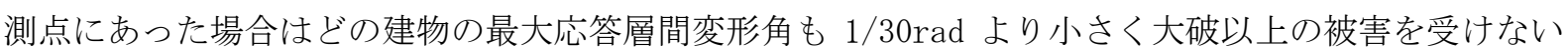
が、木造建物の最大応答層間変形角は 3 棟とも $1 / 10 \mathrm{rad}$ より大きなっており、大破以上の被害を受 ける結果になった。その中で 2005 年 3 月 20 日に起きた福岡県西方沖地震で震度 6 弱を観測された福 岡市東区に位置し、その地震で瓦被害 ${ }^{19)}$ を受けた HO 邸は今回の場合でも一階で大きく変形している。 

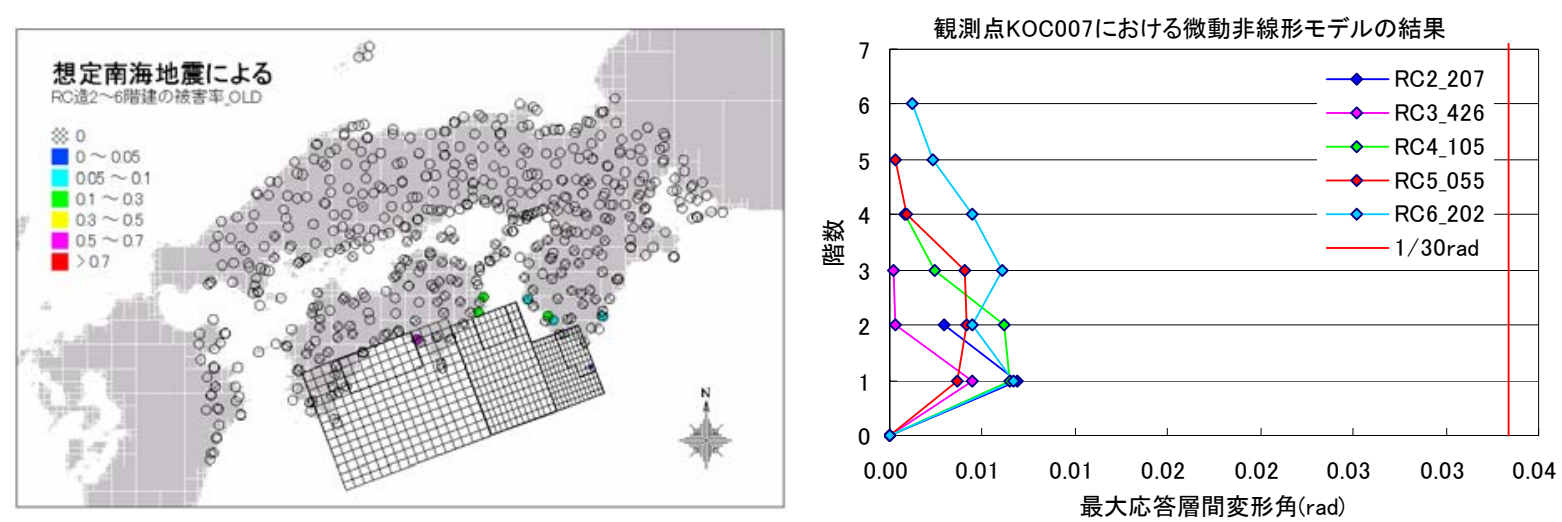

図 13 想定南海地震による RC 造 2〜6 階建の被害分布と振動状況の例
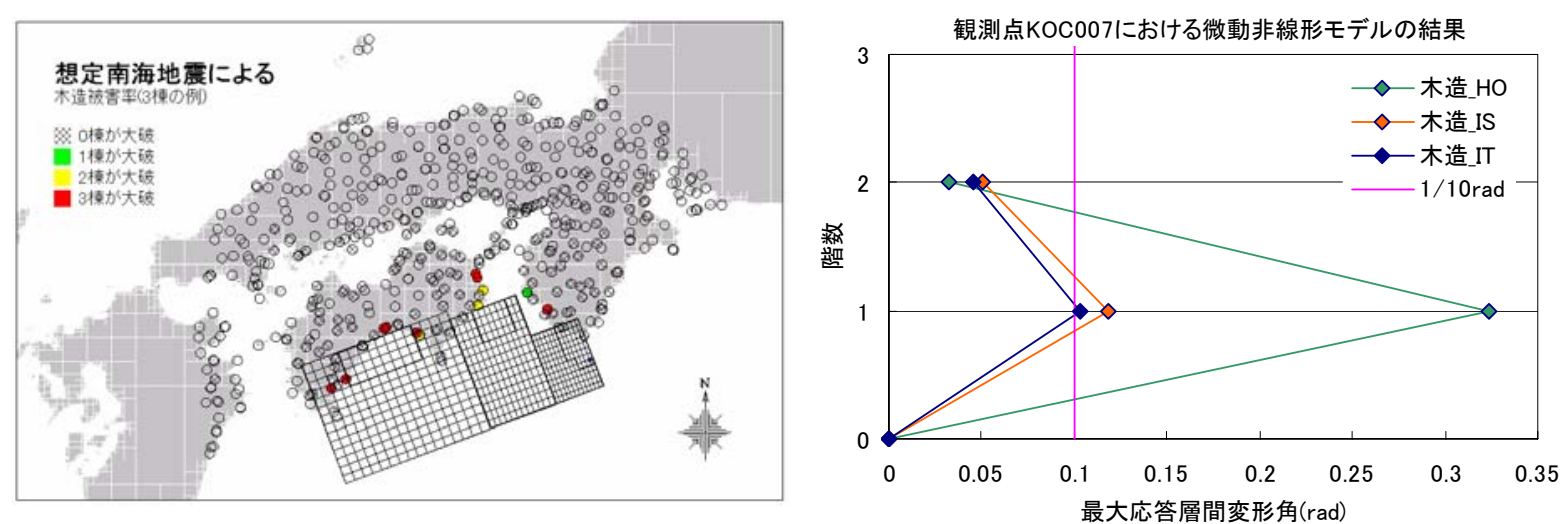

図 14 想定南海地震による 3 棟木造建物の被害分布と振動状況の例

\section{7. まとめ}

本研究ではまず全国に配置されているK-NET、KiK-net、JMA 観測点に観測された 1996 年 8 月から 2005 年 3 月にかけて発生したマグニチュード $M \geqq 5.5$ 、震源深さ $\leqq 60 \mathrm{~km}$ 、最大加速度 $\leqq 200 \mathrm{gal}$ 、最大震源距 離 $4400 \mathrm{~km}$ となる地震データを統計的に処理し、地震動の経時特性とスペクトル特性を抽出した。同定 した $\mathrm{T}_{\mathrm{r}}$ ・ $\mathrm{T}_{\mathrm{d}}$ はマグニチュード $\mathrm{M}$ や震源距離 $\mathrm{X}$ が大きくなるほど大きくなる傾向があった。その傾向は 内陸地震より海溝型地震の方が明確であり、同じマグニチュードや震源距離に対して平均的な $\mathrm{T}_{\mathrm{r}} \cdot \mathrm{T}_{\mathrm{d}}$ も大きかった。得られた内部減衰 $\mathrm{b}$ は高振動数側ほど減少寸る傾向があり、地域別にみると内陸地震 の場合は火山フロントより背弧側で九州北西部（区分 1)、火山フロントより背弧側で東北地方の日本 海側の地域（区分 5)、九州の太平洋側・中国・四国・近畿・東海地域（区分 4)、関東・東北の太平洋 側の地域（区分 2）の順に減少するが、地域ごとにそれほど大きな差が見られない。一方プレート内・ プレート間地震では火山フロントの背弧側の地域 (区分 1 - 区分 5 ・北海道北部の区分 6) で大きく減少 するが、太平洋側の前弧地域 (区分 2 ・北海道南部の区分 3 ・区分 4)ではその傾向が少ない。また、幾 何減衰 $\mathrm{n}$ に関しては、プレート内・プレート間地震では振動数に依存せずほぼ 1 であり、実体波が卓 越していることが示唆される。しかし、内陸地震の場合は振動数と震源距離に依存する傾向が見られ、 内部減衰とのトレードオフが生じている可能性があることが分かった。

次に、得られた統計的グリーン関数を用いて想定南海地震による西日本における強震動を試算した。 その結果、予測した強震度波形の形状と震度階級の分布は過去の地震や研究成果とほぼ一致していた。 また、得られた最大加速度・最大速度と経験的距離減衰式と比較したところ最大加速度はよく一致し ているのに対し、最大速度は全体的に過小評価傾向となっていることが分かった。要素地震の最大速 度自体が観測も統計的グリーン関数も小さめであり、その震源スペクトルが平均的なものではない可 能性があるが、同時に本手法では強震動を作成する時に、やや長周期成分の寄与が大きい最大速度そ 
のものについては直接的には何も規定されていないことにも関係している可能性が考えられる。全体 的な結果を総合すると、本論文で提案した内陸地震とプレート間地震、プレート内地震の三タイプ、 また日本全域を六つの地域に分けてその平均的地震特性を抽出して作成した統計的グリーン関数は概 ね妥当なものであるといえる。

最後に、統計的非線形モデル・超高層 RC 造建物のせん断質点系モデル・微動非線形応答解析モデル に想定南海地震の強震動を入力して、西日本における木造・中低層 $\mathrm{RC}$ 造・低層 $\mathrm{S}$ 造・超高層 $\mathrm{RC}$ 造建 物の被害予測を行った。その結果、高知県、徳島県、愛媛県、和歌山、大阪府、奈良県、香川県、大 分県などの海岸地域と川沿いの沖積地盤地域などの比較的地盤が軟らかいところでは建物種別を問わ ず、大破以上の被害を受ける可能性があることが分かった。しかし、超高層建物の被害は震源断層の 近いところに限られており、大阪平野など超高層建物の現存するところでは大破及び塑性変形に入る 建物はないことが分かった。また、旧耐震設計法で建てられた建物は新耐震設計法で建てられた建物 より大きな被害を受けること、建物構造種類別でみると低層鉄骨造建物、木造建物、中低層 RC 造建物 の順に被害率が小さくなることが分かった。同時に、福岡市内に存在する RC 造建物 (21 棟) と木造の建 物 ( 3 棟) が想定南海地震における対象観測点に存在しているものと仮定した場合、震源域に近い観測 点ではかなりの割合で大破となる結果になった。ただ建物が大破以上の被害を受ける観測点は全体の 1/10（震源から $400 \mathrm{~km}$ 以内の観測点）には至らなかった。これらの予測被害率分布は過去の歴史地震 の被害分布や過去の研究結果とほぼ一致している結果となった。少なくとも耐震補強など南海地震に 向けた被害対策を立案する上では、震源近傍か地盤が軟弱であるかどちらかを満たす地域を重点的に 対象とすべきであることが指摘できる。

今回の検討は、多数の観測データから地震のタイプ、地域特性を考慮して長周期まで有効な統計的 グリーン関数を作成し、さらにそれを用いて南海地震の強震動予測を行い、さらに非線形モデルを用 いて木造、中低層 $\mathrm{RC}$ 造・S 造、超高層 $\mathrm{RC}$ 造建物の被害予測を行ったものである。今後は内陸地震・プ レート内地震を含め様々な検討を行う必要性があり、さらにやや長周期域の合成方法に関して詳細な 検討を実施し、強震動および被害予測の精度の検証を重ねていくことでその実用化を目指したい。

\section{謝辞}

本論文を作成に当たっては防災科学技術研究所の K-NET、KiK-net の強震記録、F-net による地震の メカニズム解及び気象庁の強震記録を用いました。釜江克宏京大教授には震源モデルの情報を教えて いただきました。本研究の一部は、文科省科研費基盤研究 B（No. 18310125）および大大特「I．地震 動の予測」の支援を受け実施しています。ここに記して感謝の意を示します。

\section{参考文書}

1）地震調査研究推進本部：http://www. jishin. go. jp/main/index. html.

2）伊藤茂郎・川瀬博 : 統計的グリーン関数法による強震動予測法の検証と仮想福岡地震への適用, 日 本建築学会構造系論文集, 第540号, 57-64, 2001.2.

3）釜江克宏: 半経験的手法による強震動予測，20XX年の南海地震を考えるシンポジウム，建築学会近 畿支部，9-23，2002.

4）川瀬博・松尾秀典：K-NET，KiK-Net，JMA震度計観測網による強震動波形を用いた震源・パス・サ イト各特性の分離解析，日本地震工学会論文集，第4巻，第1号，33-52，2004.2.

5) Boore, D. M. : Stochastic simulation of high frequency ground motions based on seismological models of the radiated spectra, Bull. Seism. Soc. Am., Vol.73, No.6, 1865-1894, 1983.

6) Irikura, K. : Prediction of strong acceleration motions using empirical Green' s function, Proc. 7th Japan Earthq. Eng. Symp., 151-156, 1986.

7) Aki, K. : Scaling law of seismic spectrum, J. Geophys. Res., Vol. 72, No. 4, 1217-1231, 1967.

8）釜江克宏・入倉孝次郎：1946年南海地震 $(M w=8.1)$ 時の震源近傍及び周辺地域における強震動評価, 日本建築学会構造系論文集，第455号，61-71，1994.1.

9）司宏俊・翠川三朗：断層タイプ及び地盤条件を考慮した最大加速度・最大速度の距離減衰式，日本 建築学会構造系論文集，第523号，63-70，1999.9.

10）地震調査研究推進本部：地震調査委員会強震動評価部会「南海トラフの地震の長期評価について」, http://www. jishin. go.jp/main/ chousa/01sep_nankai/index.htm, 2002.

11）長戸健一郎・川瀬博：建物被害データと再現強震動によるRC造構造物群の被害予測モデル，日本建 
築学会構造系論文集，第544号，pp31-37，2001.6.

12）長戸健一郎・川瀬博：被害予測用動的構造物群モデルと福岡市の被害予測, 日本建築学会大会学術 講演梗概集(関東), pp135-136, 2001.9.

13）包那仁満都拉・川瀬博： 常時微動計測に基づく中低層RC造建物の振動特性とその而震性評価， 日 本建築学会構造系論文集，第577号，pp29-36，2004.3

14）金治寿： 超高層RC建物のせん断質点系による非線形地震応答解析，九州大学大学院人間環境学府 修士論文集，2004. 3.

15）松島信一・川瀬博： 1995 年兵庫県南部地震の複数アスペリティモデルの提案とそれによる強震動 シミュレーション，日本建築学会構造系論文集，第 534 号, pp33-40, 2000.8

16）建設院第一技術研究所 : 昭和二十一年十二月二十一日東南地震調查報告, 建設院第一技術研究所 概報，第十六号，昭和二十三年六月

17）能島暢呂：想定南海地震による被害予測について, 月刊地球，「南海地震 一次の巨大地震に備え て一」，海洋出版，号外No. 24, pp198-203. 1999.3

18）中央防災会議東南海・南海地震等に関する専門調査会：「東南海，南海地震等に関する専門調査会」 （第10回），2004，http://www. bousai.go.jp/jishin/chubou/nankai/10/siryou2.pdf

19）包那仁満都拉・川瀬博： 常時微動計測と福岡県西方沖地震の余震観測によるRC造建物・木造建物 の振動特性及び地震応答評価，日本建築学会構造系論文集，第605号，pp63-70，2006.7

\title{
Broadband Stochastic Green's Functions Based On Observed Data by Strong Motion Networks and Its Application to Nankai earthquake
}

\author{
HO Narenmandula ${ }^{1)}$ and KAWASE Hiroshi ${ }^{2)}$
}

1) Member, Guest Researcher, Faculty of Human-Environment Studies, Kyushu University, Dr. Eng.

2) Member, Professor, Faculty of Human-Environment Studies, Kyushu University, Dr. Eng.

\begin{abstract}
First we utilized Stochastic Green's functions obtained from strong motion data of K-NET, KiK-net, and the JMA Shindo-kei network in Japan to predict strong motions for a large subduction-zone earthquake. Then considering earthquake type and site characteristics, earthquake spectrum characteristics and propagation path effects were extracted. Then we used a conventional Green's function method to sum up statistical Green's functions for a moderate size earthquake and synthesize them to predict strong motions due to the expected Nankai earthquake. The resultant strong motions show similar PGA values of empirical relations and the calculated seismic intensities show similar values as observed in the previous two events.

Finally, we input these strong motions to dynamic nonlinear structural models. Our nonlinear structural models are unique because they are multiple models with different strengths with different existence ratios. From the theoretical calculations we can determine damage ratios for different types of building. For quantitative prediction we determined model parameters based on the damage statistics in Kobe after the Hyogo-ken Nanbu (Kobe) earthquake of 1995. We found that heavy damage to structures can only be found in the near-source region. We have very heavy damage ratios to low-rise steel structures, while for low-rise RC structures we have relatively small damage ratios. However, the damages in high-rise buildings were limited to those at near fault locations, and high-rise buildings in Osaka Plain did not have serious damages or plastic deformations.
\end{abstract}

Key Words: Stochastic Green's Functions, damage prediction of buildings, Nankai Earthquake prediction 